\title{
Prof. Helen Feltovich: today it's 5G, tomorrow it's 100G, who knows what can happen?
}

Submitted Sep 18, 2019. Accepted for publication Nov 25, 2019.

doi: 10.21037/atm.2019.11.146

View this article at: http://dx.doi.org/10.21037/atm.2019.11.146

\section{Editor's note}

From August $17^{\text {th }}$ to $18^{\text {th }}, 2019$, the $1^{\text {st }}$ CIMS International Medical Summit was successfully held in Beijing, China, with the focus on the popular topics in obstetrics, lung cancer, gastrointestinal cancer, proton beam therapy, neuro-oncology, neurosurgery, and other areas. During the conference, we were glad to interview Prof. Helen Feltovich (Figure 1), an expert in maternal and fetal medicine from Intermountain Healthcare. She shared with us her perspective on the future of obstetrics (Figure 2).

\section{Expert's introduction}

Helen Feltovich, MD, is an attending physician in obstetrics and gynecology at Intermountain Medicine, an assistant professor of obstetrics and gynecology at the University of Utah, and an associate researcher in the College of Medical Physics at the University of Wisconsin-Madison. She is internationally recognized as an expert in preterm delivery and quantitative ultrasound technology. Not only is she a maternal-fetal medical clinician, but she also has been a co-head of a research laboratory funded by the National Institute of Health for more than 10 years.

\section{Interview (Figure 3)}

ATM: You gave an intriguing speech about the application of AI in obstetrical practice at the conference. Could you please share with us the key points of your speech?

Prof. Feltovich: The key point of my speech is that AI is coming to obstetrics. That's what this entire conference is about: the $5 \mathrm{G}$ network and how we can all use it together all over the world to bring better health care to our pregnant patients. Today it's $5 \mathrm{G}$, tomorrow it's $100 \mathrm{G}$. Who knows what can happen? 


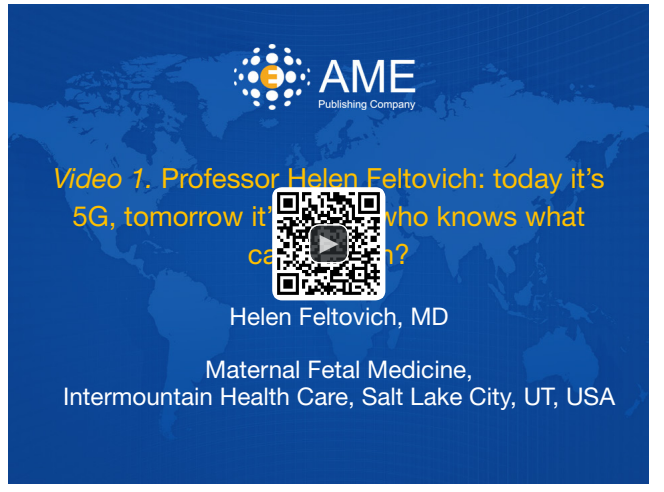

Figure 3 Professor Helen Feltovich: today it's 5G, tomorrow it's 100G, who knows what can happen? (1).

Available online: http://www.asvide.com/watch/33101

obstetric scene. Here, I've learned that the preterm birth rate in China is about the same as the preterm birth rate in the United States, and we have so much work to do. Every time we have a tiny little baby that is born, and we can't save the baby, it's dreadful. Watching those babies passing in my hands, seeing the grief on the face of the parents, is always overwhelming to me. Every case is unforgettable, and unfortunately, I have far too many of them to pick one. But my lab and many labs all over the world are doing so much research about preterm birth these days, we will find a solution together.

\section{ATM: Would you introduce us to a recent research project that you are involved in? Have you encountered any setback or challenges in your research? How did you overcome it/them?}

Prof. Feltovich: I had an advisor who once said everyday research is a challenge that we have to overcome. That's why we call it research instead of just searching. So every day is a challenge. In my lab, we work on developing non-invasive ultrasound tools to look at properties of pregnancy tissues. For example, we look at the membranes and the uterus as well through the soft, upper surface, and microstructure. And a setback we find every day is that the structures are very small and individualized. They change throughout pregnancy, and the properties of the tissues change from every woman through every pregnancy. It's a little different for every woman. Therefore, trying to adjust our technologies to that is an everyday challenge.

\section{ATM: What would be your suggestions for young doctors who are ready to pursue opportunities in your field?}

Prof. Feltovich: That's my favorite question. Because I would say follow your heart. When doctors are in medical school as residents, there is always some patient or case that grabs them. And if young doctors are open and aware of what is inspiring them, and what is making them find their passion, and they follow that road, there can be no possibility of going wrong. For me, I found my passion because of a preterm birth. Because when I was a medical student, I watched these babies being born too early and nobody could stop it, and the tremendous grief and burden on society it brings was overwhelming to me. So that's how I found my passion. And every person is a little bit different, and every person, if they are open and aware, can find their passion.

\section{Acknowledgments}

We would like to express our sincerest gratitude to Prof. Helen Feltovich for sharing her insights and opinions with us.

\section{Footnote}

Conflicts of Interest: The authors have no conflicts of interest to declare.

\section{References}

1. Bu J, Zhou A. Professor Helen Feltovich: today it's 5G, tomorrow it's $100 \mathrm{G}$, who knows what can happen? Asvide 2020;7:061. Available online: http://www.asvide.com/ watch/33101

(Science Editors: Jessie Bu, Angelia Zhou, ATM, editor@atmjournal.org)

Cite this article as: $\mathrm{Bu} \mathrm{J}$, Zhou A. Prof. Helen Feltovich: today it's $5 \mathrm{G}$, tomorrow it's $100 \mathrm{G}$, who knows what can happen? Ann Transl Med 2020;8(4):146. doi: 10.21037/atm.2019.11.146 